\title{
DEVELOPMENT OF THE COMPANY'S PERSONNEL MANAGEMENT STRATEGY AND THE TOOLS FOR ITS IMPLEMENTATION
}

The article analyzes the scientific approaches to the selection and development of the company's personnel management strategy and the tools for its implementation. Personnel management in companies is one of the most important areas of corporate strategy. The personnel development strategy should be closely aligned with the overall strategy of the company, while the mechanisms for implementing the adopted strategies should be flexible to take into account organizational changes and potential threats. A systematic approach to the development of a company personnel management strategy based on multifunctional components is proposed. It is emphasized that the development of a staff development strategy is preceded by a comparison of professional and organizational competencies of existing human resources. The influence of the stage of the company's life cycle on the development of personnel management strategy is substantiated. Personnel management strategy is defined as a long-term program of concrete measures to realize the concept of using and developing the potential of company personnel to ensure its competitive advantages. The main tools for implementing the strategy are the system of planning, budgeting, goal management, a balanced scorecard, ongoing HR management, personnel management, development activities, skills development, solving social problems, rewards and motivation. Using tools for the implementation of personnel management strategy is reflected in change in employee behavior, generally improves their work efficiency, improves social and employment relations between members of the labor collective. As a result of the research, it is proposed to use the organizational and economic mechanism as an effective tool for implementing the company's personnel management strategy. The proposed mechanism consists of functional and methodological components, in particular: definition of labor regulations, classification of personnel by functions and categories, methods of stimulation to work, methods of personnel management, indicators of personnel efficiency.

Key words: personnel, personnel management strategy, strategy evaluation, personnel management system, organizational and economic mechanism.

DOI: https://doi.org/10.32838/2523-4803/70-3-18

УДК 338.2:631.1

\section{Багорка М.O.}

доктор економічних наук, доцент кафедри маркетингу,

Дніпровський державний аграрно-економічний університет

Юрченко Н.I.

кандидат економічних наук,

старший викладач кафедри маркетингу,

Дніпровський державний аграрно-економічний університет

Bahorka Mariia, Yurchenko Nataliy

Dnipro State Agrarian and Economic University, Ukraine

\section{ЕКОЛОГІЧНО СПРЯМОВАНІ ІННОВАЦІї В ДІЯЛЬНОСТІ АГРАРНИХ ПІДПРИЕМСТВ}

Досліджені екологічно спрямовані інноващії та напрями їх реалізащиї в діяльності аграрних підприємств, щуо дасть змогу підвищити їхню конкурентоспроможність. Екологізація визнана напрямом інновачійного розвитку аграрних господарств, щзо базується на освоєні екологічних методів господарювання, забезпечує розширене відтворення природних $і$ антропогенних ресурсів за рахунок формування стійких еколого-економічних систем, спрямованих на збільшення обсягів виробництва конкурентоспроможної продукиї. Виділені основні механізми, за допомогою яких має здійснюватися прочес екологізачії: економічного регулювання та відповідальності, фінансової та державної підтримки. Основу екологічно спрямованих інновацій аграрних підприємств становлять відповідні їхні дї̈ в процесі переходу на екологічно орієнтований розвиток за єдиної послідовної державної політики.

Ключові слова: інноваційний розвиток, екологізація, аграрні підприємства, механізми екологізаиії, державна екологічна політика, система еколого-економічного управління.

Постановка проблеми. На протязі тривалого періоду проблеми екологічного стану навколишнього природного середовища стоять особливо гостро. Це пов'язано насамперед із негативним антропогенним впливом на стан природного середовища на локальному і глобальному рівнях. 
Серед галузей економіки України сільське господарство належить до найбільш впливових і чутливих до змін навколишнього середовища, бо організовує своє виробництво на великих територіях, а кінцевий результат позначається на якості сільськогосподарської продукції. За сучасних умов якість та екологічна безпечність продукції $є$ важливою вимогою споживачів і умовою виходу вітчизняних товарів агропромислового виробництва на європейський ринок. Для України вихід продовольчих товарів на європейський ринок має ключове значення і вимагає змін у веденні аграрного бізнесу.

Відповідно до сучасних умов перед аграрною галуззю України постає завдання зробити виробництво продуктів харчування більш екологічним, а для цього необхідно перевести систему господарювання аграрних підприємств на новий інноваційний рівень, де перевага надається екологічно безпечному розвитку. Отже, проблема переходу аграрних підприємств на модель інноваційного й екологічно збалансованого розвитку є актуальною, а необхідність у екологізації аграрного виробництва не викликає сумніву та потребує негайного пошуку шляхів переходу аграрних підприємств на екологічно орієнтовані методи господарювання.

Аналіз останніх досліджень і публікацій. Еколого-економічні аспекти функціонування сільськогосподарських підприємств досліджено в працях В.А. Борисової, П.С. Березівського, Н.В. Зіновчука, О.М. Царенка; проблеми формування і встановлення ресурсо-екологічної та продовольчої безпеки досліджували П.А. Лайко, В.М. Трегобчук та інші вчені.

Наукові дослідження, присвячені вивченню процесу екологізації аграрного виробництва та формуванню механізму екологічного регулювання, в останні роки проводили І.С. Воронецька, А.С. Малиновський, Л.Г. Мельник, О.В. Прокопенко, О.О. Прутська, О.Л. Попова, А.Я. Сохнич, А.М. Третяк, Л.А. Хромушина, О.І. Шкуратов тощо.

Незважаючи на наявність досить прогресивних, науково обгрунтованих розробок, значна частина питань, пов'язаних із переходом аграрних підприємств до екологічно орієнтованого інноваційного розвитку, потребує подальшого дослідження.

Формулювання цілей статті. Мета дослідження полягає у розробленні екологічно спрямованих інновацій та напрямів їх реалізації в діяльності аграрних підприємств, що дасть змогу підвищити їхню конкурентоспроможність за рахунок упровадження новітніх технологій, видів продукції, методів управління, стратегії розвитку.

Виклад основного матеріалу. Вже багато років екологічна ситуація в Україні визначається як кризова, що насамперед негативно позначається на якості продукції та здоров’ї людини. Причиною цього $€$ довготривалий процес інтенсифікація виробництва в аграрній сфері економіки, який має не лише позитивні, а й негативні наслідки для галузі. Останніми роками цей процес зумовив загострення екологічної кризи і створив низку проблем екологічного характеру, які ставлять під сумнів правильність сучасної системи господарювання.

Інноваційний підхід дасть змогу підвищити ефективність та конкурентоспроможність аграрних підприємств, зміцнити позиції аграрних товарів на міжнародному ринку, підсилити економічний потенціал держави та рівень екологічності продукції на національному рівні.

Ми переконані, що екологізація є основним напрямом інноваційного розвитку аграрних підприємств. I для іiї реалізації є всі соціальні, політичні й економічні передумови. Процес екологізації господарської діяльності аграрних підприємств передбачає систему цілеспрямованих перетворень, які спрямовані на зниження негативного впливу на природне середовище за ефективного використання ресурсів у процесі виробництва, зберігання, транспортування та реалізації продукції.

Водночас в аграрній сфері економіки розвиток інноваційної діяльності, на жаль, стримується через недостатнє стимулювання цих процесів 3 боку держави, через обмеженість внутрішніх і зовнішніх джерел фінансування інновацій та труднощі щодо їх швидкої мобілізації. Ефективне ведення господарської діяльності на інноваційній основі є також обмеженим через нестабільне фінансово-економічне становище більшості сучасних малих та середніх сільськогосподарських підприємств, а також домогосподарств населення, які становлять більшість у сукупності суб'єктів агробізнесу.

О.В. Шубравська зазначає, що «людство починає глибше усвідомлювати загрози, які несуть у собі негативні тенденції у динаміці показників стану соціальної та екологічної компонент суспільного розвитку. Це спонукає до більш активного впровадження наукових розробок стосовно забезпечення екологічно збалансованого і соціально орієнтованого економічного зростання на інноваційній основі» [1, с. 62].

Елементами екологічно спрямованих інновацій $\epsilon$ ресурсо- та енергозбереження. В умовах виснаження природно-ресурсного потенціалу ці критерії $€$ особливо важливими. Для аграрних підприємств важливо досягти максимального рівня окупності витрат, підвищити обсяги виробництва і реалізації сільськогосподарської продукції, сприяти надходженню інвестицій та їх рентабельності, але при цьому в умовах екологізації структура агровиробництва має забезпечити мінімальний антропогенний вплив на навколишнє середовище.

I.M. Синявська відзначає, що «основу для інноваційного розвитку створюють економічні суб'єкти, що здійснюють інноваційну діяльність із метою отримання вигод. Проте іiі результативність залежить від стану зовнішнього і внутрішнього економічного середовища, наявності необхідних умов для впровадження й раціонального використання інноваційної продукції» [2, с. 258]. 
С.В. Сирцева визначає, що інноваційні технології в аграрному виробництві $є$ економічними моделями, до складу яких входять елементи біологічного землеробства за збереження екологічної рівноваги у природних і антропогенних системах, а організація процесу виробництва дає змогу досягти високого рівня менеджменту, адаптації до факторів середовища та ефективності виробництва [3, с. 115-116].

Основою екологізація діяльності аграрних підприємств виступає раціональне використання природноресурсного і виробничого потенціалу, що, з одного боку, має сприяти підвищенню ефективності виробництва, а з іншого - забезпечити екологічну безпечність продукції.

Основу екологічно спрямованих інновацій становлять прогресивні технології, сучасні науково-технічні досягнення.

Деякі аграрні підприємства намагаються інтегрувати передові науково-технічні розробки й адаптувати ix у власне виробництво. Свідченням цього $є$ використання новітніх технологій у землеробстві, рослинництві та тваринництві провідними українськими підприємствами. Так, вітчизняний агрохолдинг «Kernel», який входить до перших двадцяти найпотужніших світових агрокомпаній, протягом останніх років активно застосовує широкий спектр інноваційних рішень. На полях компанії функціонують системи метеорологічного моніторингу 3 мережею власних метеостанцій та GPS-навігації, здійснюється моніторинг стану посівів за допомогою супутників i безпілотників. Картографування дало змогу досягти правильного внесення добрив, що збільшило врожайність вирощуваних культур за останні три роки в середньому на 20\% і знизило обсяг споживаних ресурсів. Точне землеробство стало стимулом для створення в компанії комплексної інформаційної системи \#DigitalAgriBusiness, яка буде акумулювати та обробляти всі дані з полів і на основі їхнього аналізу пропонувати фахівцям компанії алгоритм необхідних дій. У компанії реалізується окремий великий проект, який передбачає стандартизацію парку тракторів, комбайнів, причіпного обладнання, обприскувачів, щоб він повністю дистанційно контролювався за єдиними стандартами.

Результатом використання інноваційних технологій в агровиробництві є створення інноваційного продукту (органічної продукціі), який пов'язаний із підвищеними вимогами споживачів до якісних характеристик продуктів харчування.

Екологічно збалансований розвиток аграрного виробництва передбачає поєднання певних систем: політичної, економічної, технологічної, соціальної, міжнародної. При практичній реалізації екологічно збалансованого розвитку в діяльності аграрних підприємств важливо поєднати принцип соціальної екологічної відповідальності та соціального екологічного мотивування. Зазначені принципи базуються на матеріальних і духовних цінностях членів суспільства.
Ми переконані, що екологізація виробництва розглядається як певний процес дій, заходів, за допомогою яких відбувається управління природокористуванням, яке спрямоване на покращення якості довкілля, а також є складником інноваційної діяльності, яка спрямована на покращення якості (безпеки) життя людей.

Відповідно до «Стратегії інноваційного розвитку пріоритетних галузей аграрного виробництва» виділені стратегічні завдання та визначені стратегічні орієнтири і пріоритетні напрями агропродовольчої сфери [4, с. 135] які включають: підвищення ефективності використання ресурсного потенціалу під час впровадження ресурсозберігаючих технологій; дотримання якісних параметрів виробництва та підвищення рівня конкурентоспроможності продукції; забезпечення екологічної складової виробничого процесу; активізація інвестиційної діяльності за рахунок зовнішніх джерел фінансування; надання пріоритетності вітчизняним товаровиробникам.

Процес екологізації аграрного виробництва передбачає встановлення цілей, завдань та механізмів, спрямованих на підвищення його ефективності. Для реалізації цілей та вирішення поставлених завдань слід розробити дієвий інструментарій, основу якого має становити цілеспрямована державна політика, яка грунтується на відповідній нормативно-правовій основі та передбачає розроблення екологічно спрямованих державних, галузевих і регіональних програм [5, с. 99].

Важливо звернути увагу на складові механізми, які сприяють процесу екологізації аграрного виробництва (рис. 1).

До складу наведених механізмів екологізації входить сукупність методів управління: організаційних, економічних, техніко-технологічних, адміністративних.

Водночас варто відзначити, що на шляху до екологізації в Україні нині практично відсутня єдина послідовна державна політика, основу якої мають становити дієві механізми запровадження та реалізації принципів раціонального природокористування 3 мінімізацією негативного впливу на екологічні об'єкти під час здійснення антропогенної діяльності. Залишається також проблемою слабкий рівень функціонування державної системи моніторингу довкілля, недосконала нормативно-правова база, низький рівень координації діяльності суб'єктів екологічного моніторингу, недостатні обсяги фінансування тощо.

Необхідно на державному і регіональному рівнях реалізовувати заходи екологічної політики (рис. 2).

Дієві механізми регулювання та стимулювання екологізації мають бути впровадженні як на державному рівні, так і на рівні підприємства. Це дасть змогу стабілізувати екологічну ситуацію через зміну орієнтації соціально-економічного розвитку, формування нових цінностей, перегляду структури потреб, цілей, пріоритетів і способів діяльності людини.

У результаті виробнича діяльність аграрних підприємств має бути переведена на принципово нову 


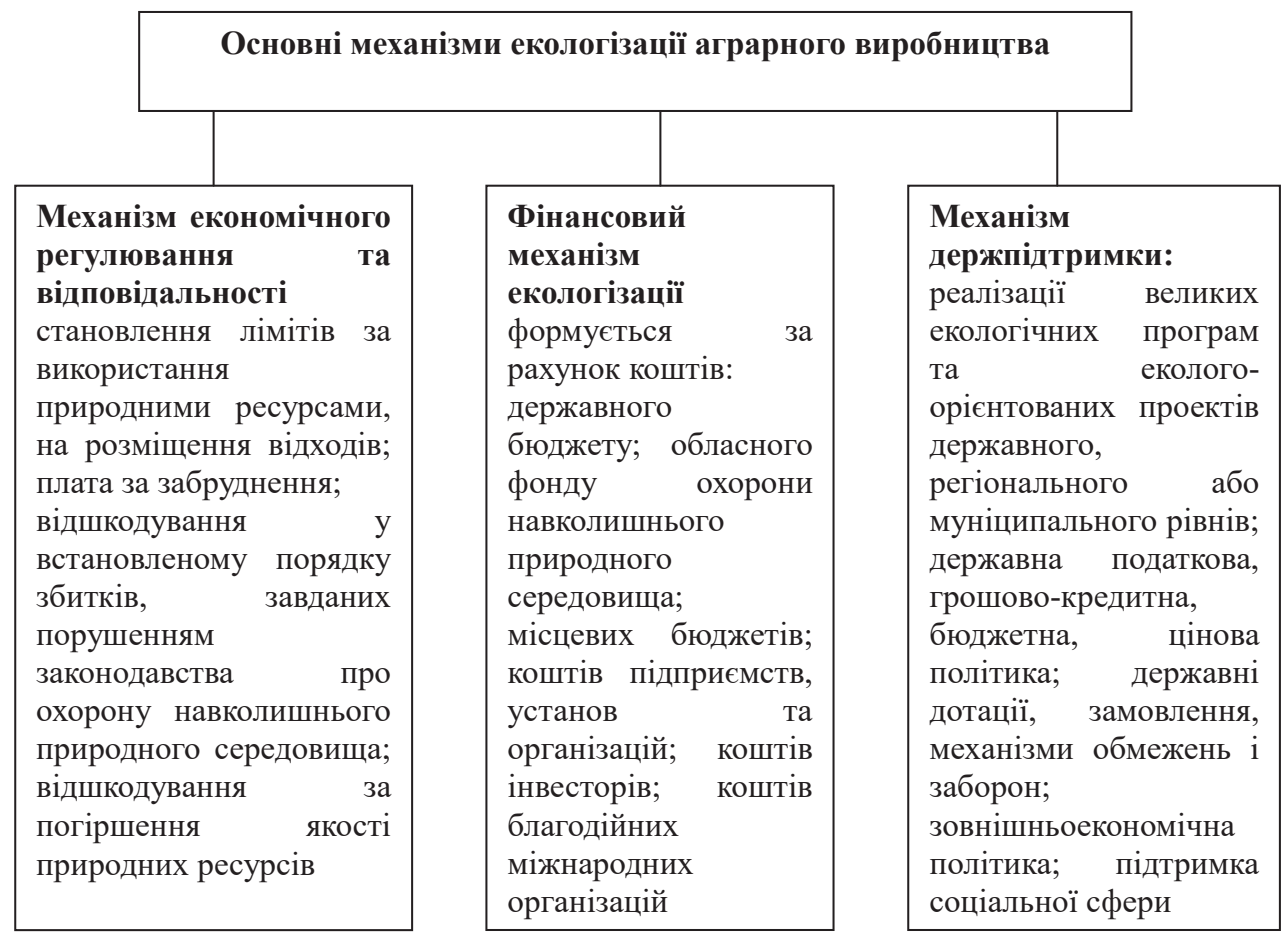

Рис. 1. Основні механізми екологізації аграрного виробництва

Джерело: узагальнено авторами

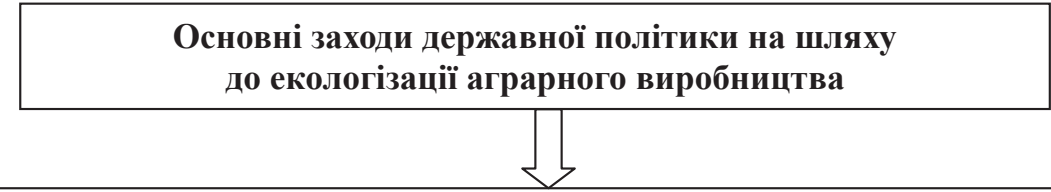

- стимулювати ведення грунтозахисного сільського господарства (запровадження преференцій прогресивним підприємствам), зокрема екологічного, що позитивно вплине на практику землеробства загалом;

- встановити жорсткий контроль за дотриманням аграрними підприємствами сучасних екологічних норм;

- забезпечити економічну безпеку (конкурентні умови) виробникам сільськогосподарської продукції, що сприятиме економічному зростанню;

- переглянути 3 погляду первинності інтересів споживача стандарти якості сільськогосподарської продукції та наблизити їх до європейських, що сприятиме конкурентоспроможності на зовнішніх ринках;

- відстоювати інтереси споживачів та гарантувати безпеку харчових продуктів.

Рис. 2. Основні заходи державної політики на шляху до екологізації аграрного виробництва

Джерело: узагальнено авторами

економіко-технологічну основу, структурна перебудова виробництва повинна здійснюватися 3 урахуванням екологічних факторів, законів, вимог і нормативів, що є обов'язковою умовою подолання екологічної кризи в аграрному секторі економіки.

В основу екологічно-орієнтованого господарювання аграрних підприємств має бути покладено принцип підвищення соціальних та економічних ефектів, що проявляється у збереженні та покращенні стану навколишнього природного середовища, збільшенні потреби у трудових ресурсах тощо. Процес переходу на органічне агровиробництво пов'язаний $з$ новими прогресивними технологіями, спрямованими на очищення використовуваних видів сировини, матеріалів, утилізацію відходів, впровадження безвідходних технологій, та зі значними інвестиціями. Вибір моделі розвитку органічного агровиробництва на основі екологічно спрямованих інновацій визначається балансом 
між економічними та екологічними інтересами, і при цьому обмеження щодо екологічності повинні бути достатньо жорстокими.

Екологічно орієнтоване господарювання аграрних підприємств базується на поєднанні стратегічного підходу із системою менеджменту природокористування. При цьому важливо зауважити, що якщо для загальноприйнятої стратегії досить традиційної системи менеджменту навколишнього середовища, орієнтованої на виконання певних зобов'язань перед державою, то для досягнення конкурентної переваги на світовому ринку необхідно перебудовувати наявну систему господарювання за вимогами міжнародних стандартів.

Ключові напрями переходу аграрних підприємств на модель інноваційного розвитку на засадах екологізації та сталого розвитку наведені на рис. 3.

Для реалізації цих напрямів необхідно зробити цілу низку якісних перетворень, які стосуються переходу на інноваційний розвиток, оновлення структури виробництва, подолання значної диференціації доходів, тобто необхідна глобальна модернізація національної економіки.

Також процес переходу на органічне виробництво пов'язаний із новими технологічними інноваціями, спрямованими на очищення використовуваних видів сировини, матеріалів, утилізацію відходів, впрова- дження безвідходних технологій, сучасними методами утримання тварин і значними інвестиціями в галузь.

Серед ключових принципів та умов екологічно орієнтованого розвитку варто виокремити системність, наукове обгрунтування, економічність і результативність, прозорість та інформативність. Принципи мають відповідати: реальності (відповідності ситуації, цілям, виробничим, ринковим та ресурсним факторам, досвіду та навичкам системи управління); логічності (внутрішньої цілісності та несуперечливості окремих елементів); сумісності із зовнішнім середовищем (забезпечення можливості взаємодії з ним); виправданій ризикованості та спрямованості на формування стійких конкурентних переваг.

Узагальнюючи вищезазначене, можна виокремити основні шляхи екологічно орієнтованої перебудови виробничої діяльності аграрних підприємств:

- раціональне використання земельних ресурсів, що супроводжується збереженням і підвищенням родючості грунту;

- забезпечення оптимального рівня розораності земельних угідь, що унеможливить розвиток водної і вітрової ерозії грунту;

- удосконалення галузевої структури органічних господарств за критерієм імплементації стратегії екологізації виробництва, що передбачає збільшення

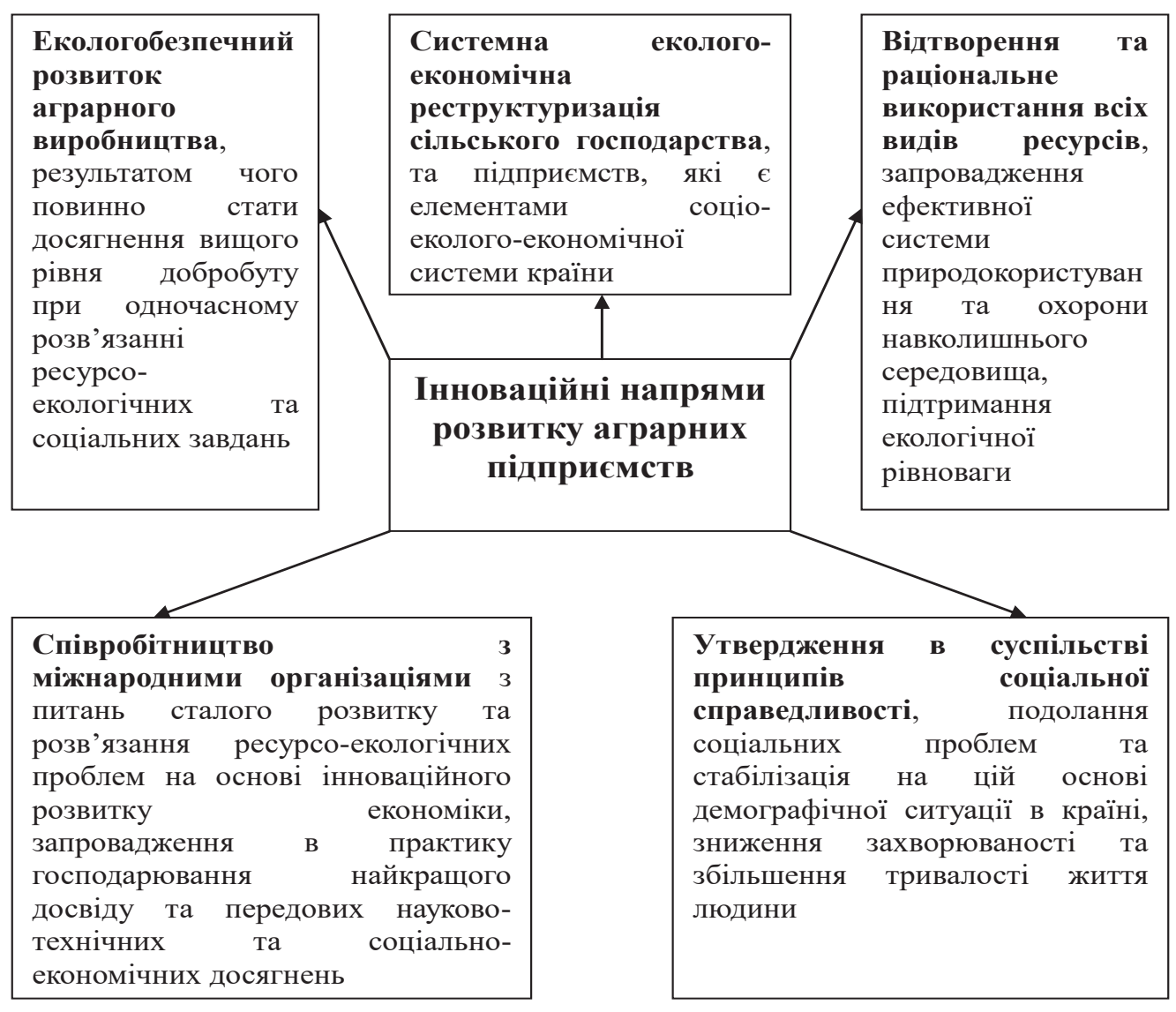

Рис. 3. Основні інноваційні напрями розвитку аграрних підприємств

Джерело: узагальнено авторами 
площ посіву зернових та кормових культур за рахунок технічних у галузі рослинництва та поголів'я великої рогатої худоби - у галузі тваринництва;

- використання прогресивних технологій мінімальної обробки грунту й точного землеробства;

- дотримання вимог недопущення перевищення гранично допустимих норм забруднення виробництва продукції, забезпечення їі екологічності;

- дотримання встановлених правил щодо транспортування, складування і внесення мінеральних добрив, засобів захисту рослин і тварин;

- застосування ресурсозберігаючих органічних технологій вирощування сільськогосподарських культур, що приводить до зменшення собівартості вирощування продукції за рахунок внесення органічних добрив, застосування біологічних та механічних прийомів боротьби з бур'янами;

- особливу увагу слід приділити умовам очищення, сортування, сушіння та зберігання зерна. Якісно проведені технологічні операції дадуть змогу підвищити якість зерна, внаслідок чого підвищиться конкурентоспроможність продукції. Під час переробки завдяки сучасним та традиційним натуральним технологіям органічна продукція зберігає свою безпечність, натуральний склад, поживні властивості, гарні смакові якості, не містить синтетичних ароматизаторів, консервантів, харчових добавок та пакується в натуральні матеріали;

- застосування енергозберігаючих технологічних процесів для зниження виробничої собівартості та виділення резерву вивільнених коштів під витрати на збут продукції;

- дотримання екологічних вимог під час проектування, будівництва і введення в експлуатацію нових будівель та споруд, меліоративних систем тощо.

Отже, для здійснення переходу до екологічно орієнтованого господарювання варто змінити принципи функціонування суб'єктів агробізнесу, прискорити їхній інноваційний розвиток та забезпечити можливість їх організаційних трансформацій.
Висновки. Проблеми економічного зростання, підвищення конкурентоспроможності аграрної галузі можуть бути вирішені за допомогою ефективних стратегій i механізмів інноваційного розвитку. Ми вважаємо, що екологізація виробництва аграрних підприємств $є$ основним напрямом їхньої інноваційної діяльності, яка забезпечить високу якість життя, національну безпеку, охорону довкілля та високий технічний рівень аграрного виробництва в Україні.

Процес екологізації виробництва аграрних підприємств слід розглядати в розрізі застосування альтернативних систем господарювання, основу яких становлять агроекологічні принципи раціонального приррдокористування і система еколого-економічного менеджменту.

Впровадження інновацій приводить до підвищення продуктивності праці, економії ресурсів, скорочення витрат та зниження собівартості аграрно-продовольчої продукції, нарощування обсягів і підвищення ефективності сільськогосподарського виробництва, що загалом сприяє залученню інвестицій. Одним із пріоритетів інноваційної політики для аграрних підприємств має стати державна підтримка.

Виділені основні механізми, за допомогою яких має здійснюватися процес екологізації: економічного регулювання та відповідальності, фінансової та державної підтримки. Ключова роль введення в дію цих механізмів належить єдиній послідовній державній політиці щодо екологізації аграрного виробництва з метою мінімізації негативного антропогенного впливу.

Виробнича діяльність аграрних підприємств має бути переведена на принципово нову інноваційну економіко-технологічну основу за суттєвої структурної перебудови виробництва, з урахуванням екологічних факторів, законів, вимог і нормативів, що є обов'язковою умовою подолання екологічної і продовольчої кризи в державі. Поступовий перехід аграрного виробництва на екологічно безпечний розвиток здатен забезпечити конкурентноздатність галузі.

\section{Список літератури:}

1. Шубравська О.В. Ризики сталого розвитку АПК України в умовах глобалізації. Економіка України. 2007. № 2. С. 62-68.

2. Синявська I.M. Формування інноваційної стратегії аграрного підприємства. Вісник аграрної науки Причорномор'я. 2010. № 6 (47). С. 258-261.

3. Сирцева С.В. Інноваційний потенціал як складова економічного потенціалу сільськогосподарського підприємства. Вісник аграрної науки Причорномор'я. 2008. № 4 (47). С. 115-121.

4. Крюкова І.О., Непочатенко В.О. Стратегія інноваційного розвитку пріоритетних галузей аграрного виробництва. Економіка: реалії часу. Науковий журнал. 2013. № 4 (9). С. 133-141.

5. Синякевич I.М. Екологізація розвитку: суть, об'єктивна необхідність, принципи, інструменти, перспективи для України. Науковий вісник ЛНЛУ. 2005. Вип. 15.6. С. 98-102.

\section{References:}

1. Shubravs`ka O.V. (2007). Ryzyky stalogo rozvytku APK Ukrayiny v umovax globalizaciyi [Risks of sustainable development of agro-industrial complex of Ukraine in the conditions of globalization]. Ukraine economy, no. 2, pp. 62-68.

2. Synyavska I.M. (2010). Formuvannya innovacijnoyi strategiyi agrarnogo pidpry`yemstva [Formation of innovative strategy of agricultural enterprise]. Bulletin of Agrarian Science of the Black Sea Coast, no. 6(47), pp. $258-261$. 
3. Syrceva S.V. (2008). Innovacijnyj potencial yak skladova ekonomichnogo potencialu silskogospodarskogo pidpry yemstva [Innovative potential as a component of the economic potential of an agricultural enterprise]. Bulletin of Agrarian Science of the Black Sea Coast, no. 4(47), pp. 115-121.

4. Kryukova I.O., Nepochatenko V.O. (2013). Strategiya innovacijnogo rozvytku priorytetnyx galuzej agrarnogo vyrobnycztva [Strategy of innovative development of priority branches of agricultural production]. Scientific journal. Economy: the realities of time, no. 4(9), pp. 133-141.

5. Synyakevych I.M. (2005). Ekologizaciya rozvy`tku: sut’, obyektyvna neobxidnist’, pryncypy, instrumenty, perspektyvy dlya Ukrayiny [Ecologization of development: essence, objective necessity, principles, tools, prospects for Ukraine]. Scientific Bulletin of LNLU, vol. 15.6, pp. 98-102.

\section{ЭКОЛОГИЧЕСКИ НАПРАВЛЕННЫЕ ИННОВАЦИИ В ДЕЯТЕЛЬНОСТИ АГРАРНЫХ ПРЕДПРИЯТИЙ}

Исследовань экологически направленнье инновации и пути их реализаџии в деятельности аграрньх предприятий, что позволит повысить их конкурентоспособность. Экологизация признана направлением инновационного развития аграрных хозяйств, основанного на освоении экологических методов хозяйствования, что обеспечивает расширенное воспроизводство природных и антропогенных ресурсов за счет формирования устойчивых эколого-экономических систем, направленных на увеличение объемов производства конкурентоспособной продукции. Выделены основные механизмы, с помощьюю которых должен осуществляться процесс экологизации: экономического регулирования и ответственности, финансовой и государственной поддержки. Основу экологически направленных инноваций аграрных предприятий составляют соответствуюшие их действия в процессе перехода на экологически ориентированное развитие при единой последовательной государственной политике.

Ключевые слова: инновационное развитие, экологизаџия, аграрные предприятия, механизмы экологизации, государственная экологическая политика, система эколого-экономического управления.

\section{ENVIRONMENTALLY DIRECTED INNOVATIONS IN THE ACTIVITIES OF AGRICULTURAL ENTERPRISES}

The article investigates and generalizes theoretical and methodological approaches to the formation of a complex marketing system; own vision is presented, and the role of integrated marketing system in the overall enterprise management system is investigated; the features of management of the marketing complex at the enterprise are considered; the methodical approach to the formation of a comprehensive marketing system, which combines the marketing complex with the marketing management system, is proposed. Integrated enterprise marketing system is an internally organized with respect to the external environment a set of interconnected components, the integral unity of which, on the one hand, satisfies the needs of consumers, and on the other-the achievement of economic sub is the object of the set goals. This is real, provided the purposeful and effective functioning of the system of such subsystems as marketing information, marketing complex, marketing management. Ecologically oriented innovations and directions of their realization in activity of the agricultural enterprises that will allow to increase their competitiveness are researched. Ecologization is recognized as a direction of innovative development of agricultural farms, based on the development of ecological management methods, provides expanded reproduction of natural and anthropogenic resources through the formation of sustainable ecological and economic systems aimed at increasing the production of competitive products. The main mechanisms by which the ecologization process should be carried out are identified: economic regulation and responsibility, financial and state support. The main mechanisms by which the ecologization process should be carried out are identified: economic regulation and responsibility, financial and state support. The production activity of agricultural enterprises should be transferred to a fundamentally new innovative economic and technological basis, with the restructuring of production, which should be carried out taking into account environmental factors, laws, requirements and standards, which is a prerequisite for overcoming environmental and food crisis. The gradual transition of agricultural production to environmentally friendly development can ensure the competitiveness of the industry.

Key words: innovative development, ecologization, agricultural enterprises, environmental mechanisms, the state environmental policy, the system of environmental and economic management. 